\title{
Short Communication: Sensory evaluation and nutritional value of Acehnese bhoi cake with pumpkin flour substitution
}

\author{
SURYATI SUFIAT ${ }^{1}$, SAFRIDA SAFRIDA ${ }^{2}$, YULI HEIRINA HAMID ${ }^{1}$, RAHMI KAMAL ${ }^{1}$, \\ RUHYAT PARTASASMITA ${ }^{3, \bullet \varphi}$ \\ ${ }^{1}$ Department of Family Welfare Vocational Education, Faculty of Teacher Training and Education, Universitas Syiah Kuala. Darussalam, \\ Banda Aceh 2311, Aceh, Indonesia. \\ ${ }^{2}$ Department of Biology Education, Teacher Training and Education Faculty, Universitas Syiah Kuala Darussalam, Banda Aceh, 2311, Aceh, Indonesia. \\ ${ }^{3}$ Department of Biology, Faculty of Mathematics and Natural Sciences, Universitas Padjajaran. Jl. Raya Bandung-Sumedang Km 21 Jatinangor, \\ Sumedang 45363, West Java, Indonesia. Tel.: +62- 22-7797712, ”email: rp2010rikkyo@gmail.com; ruhyat.partasasmita@unpad.ac.id
}

Manuscript received: 26 June 2019. Revision accepted: 31 July 2019

\begin{abstract}
Sufiat S, Safrida S, Hamid YH, Kamal R, Partasasmita R. 2019. Short Communication: Sensory evaluation and nutritional value of Acehnese bhoi cake with pumpkin flour substitution. Nusantara Bioscience 11: 142-145. Bhoi cake is one of the traditional Acehnese dry snacks with basic ingredients of rice flour or wheat flour, castor sugar, eggs and vanilla. This study aims to evaluate nutritional value and consumer acceptance by organoleptic tests on bhoi cake substituted with pumpkin flour. Design of the study was a Completely Randomized Design (CRD) with 4 treatments and three replications. The treatments was the various level of pumpkin flour substitution $(0 \%, 20 \%, 30 \%$, and $40 \%)$. Consumer acceptability with the organoleptic test was carried out by 20 panelists, namely students of the Faculty of Teacher Training and Education Syiah Kuala University using a 5 points hedonic scale. The results showed that the nutritional value of bhoi cake with pumpkin flour substitution was good and have appropriate nutritional value. Sensory evaluation by organoleptic test showed that $30 \%$ pumpkin flour substitution was the best formula preferred by the panelist. Taste, aroma, color, texture and overall acceptability of formula $\mathrm{C}$ (30\% substitution of pumpkin flour) of bhoi cake had the highest score (likes), with the characteristics of the bhoi cake were golden yellow, fragrant aroma, sweet taste, and soft texture.
\end{abstract}

Keywords: Bhoi cake, pumpkin flour substitution, consumer acceptance, nutritional value

\section{INTRODUCTION}

Bhoi cake is a snack in the form of dry snack or pastry in Aceh. The basic ingredient is rice flour or medium protein wheat flour. Medium protein flour is wheat flour originated from medium or soft wheat which has a rather yellowish-white color and contains a protein called gluten. Besides rice flour or wheat flour, bhoi cake also contains castor sugar, eggs, and vanilla. The use of sugar is not only for flavoring, but also to maintain color and food endurance. The function of eggs in making bhoi cakes is to bind the dough so that the dough can blend, improve nutritional value, to make the cake colored, produce smooth cake crumbs and make the dough expand. Vanilla is a powder-producing plant from vanilla which is used as a food fragrance. An increase in sugar content in half-short cake from 200 to $1000 \mathrm{~g} / \mathrm{kg}$ flour linearly increased the hardness from 12.5 to $22.5 \mathrm{~N}$ and the chewing ability from 7.2 to $15.6 \mathrm{~N}$ (Kusińska 2007)

The cooking process is usually done by traditional roasting of the dough in the pan containing gravel sand. Bhoi cakes which cooked traditionally have a better taste and distinctive aroma compared to bhoi cakes which cooked by using the oven. The roasting temperature is $160^{\circ} \mathrm{C}-200^{\circ} \mathrm{C}$. Bhoi cakes are often served in various celebratory events such as a wedding, birth or circumcision and the delivery for the bride.

One effort to reduce the use of wheat flour is to use substitute flour, wheat flour is available in limited quantities and is usually imported, among others, the use of yellow pumpkin flour. It is also a form of food diversification. Yellow pumpkin is spread throughout most parts of Aceh and is easily found in traditional markets. Young pumpkins are used as vegetables, while the mature one is used as ingredients for cookies, cakes, and compote. Proximate composition of the pumpkin pulp varied between 75.8 and $91.33 \%$ moisture, 0.2 and $2.7 \%$ crude protein, 0.47 and $2.1 \%$ crude ash and 3.1 and $13 \%$ carbohydrate content (Chigwe and Saka 1994). Pumpkin has $10,71 \mathrm{~g} / 100 \mathrm{~g}$ carbohydrate content, so it has the potential to be processed into flour. In 100 grams of pumpkin contains 29 calories, rich in vitamins $\mathrm{A}, \mathrm{B}, \mathrm{C}$, and minerals (Directorate of Nutrition, Ministry of Health of the Republic of Indonesia 1996; Chigwe and Saka 1994). Pumpkin has a total sugar content of $0.62 \%$, (Joshi and Panesar 2017). Yellow pumpkin contains carotenoid, which has health benefits. According to Shahidan (2014), yellow pumpkin contains carotenoids which are $\alpha$-carotene; ranging from $1.26-10.20 \mathrm{mg} / 100 \mathrm{~g}$, and $\beta$-carotene as much as $29.16-154.76 \mathrm{mg} / 100 \mathrm{~g}$ (Shahidan 2014). 
Pumpkin flour has several advantages over fresh fruit; total carotenoids and total phenolics in fresh pumpkin fruit $86.3 \mu \mathrm{g} / \mathrm{g}$ of and $905.9 \mu \mathrm{g} \mathrm{GAE} / \mathrm{g}$ (Zdunic et al. 2015). IC50 value for steamed pumkin is $37.12 \mathrm{nM}$ TE / 100g DM and for fresh pumpkin $15.98 \mathrm{nM}$ TE / 100g DM, it shows better antioxidant activity than fresh pumpkin, it shows better antioxidant activity than fresh pumpkin (Nakhon et al. 2017), longer shelf life \pm 2 months, (Hendrasty 2003) due to low water content (Sinaga 2011). It has to be stored in a dry place. This study aims to evaluate the nutritional value and determine consumer acceptance by the organoleptic test of bhoi cakes which partly substituted with pumpkin flour

\section{MATERIALS AND METHODS}

This study used a Completely Randomized Design with 4 treatments and 3 replications, The treatments used were 4 bhoi cake formulas with different levels of substituted wheat flour with pumpkin flour, i.e: A (control, 0\% pumpkin flour), B (20\% pumpkin flour), C (30\% pumpkin flour), and D (40\% pumpkin flour) respectively.

\section{Materials}

The ingredients used in bhoi cake were medium protein wheat flour, pumpkin flour, castor sugar, egg and vanilla, charcoal and coconut fiber as fuel.

\section{Research design}

The Bhoi cake produced from this study is a bhoi made with a various level of substitutions of wheat flour with pumpkin flour. The substitution levels of pumpkin flour were $0 \%, 20 \%, 30 \%$, and $40 \%$.

\section{Preparation of yellow pumpkin flour}

In the process of making bhoi cakes, pumpkin before use is processed first into flour through the drying process, after drying in the milled until smooth, then sifted using a soft sieve. Fresh pumpkin was split, the rind was peeled, and seeds were removed, washed and drained. The flesh of pumpkin was sliced thinly and dried under sunshine for 3 days. The dried sliced pumpkin was ground using a blender or pounded into flour and sieved through a very fine sieve (Balkis 2015).

\section{Preparation of bhoi cake}

Eggs, sugar, and vanilla were beaten until thickened and turned pale yellow. Wheat flour and yellow pumpkin flour were added little by little and stirred until blended. Formulation of bhoi cake $\mathrm{A}=100 \%$ wheat flour and $0 \%$ pumpkin flour, $\mathrm{B}=80 \%$ wheat flour and $20 \%$ pumpkin flour, $\mathrm{C}=70 \%$ wheat flour and $30 \%$ pumpkin flour, D $=60 \%$ wheat flour and $40 \%$ pumpkin flour. The mixture was put into a hot mold that has been smeared with edible oil, then baked on top of neuleuk (soil pot containing gravel) and cover the top, for 15 minutes. After the bhoi cake turns yellow, lift it and cool until reach room temperature. Store in a dry and tightly closed containers (Balkis 2015).
Table 1. Formulation of bhoi cake with different substitution of wheat flour by pumpkin flour

\begin{tabular}{lcc}
\hline \multirow{2}{*}{ Formula } & \multicolumn{2}{c}{ Materials } \\
\cline { 2 - 3 } & Wheat flour (\%) & Pumpkin flour (\%) \\
\hline $\mathrm{A}$ & 100 & 0 \\
$\mathrm{~B}$ & 80 & 20 \\
$\mathrm{C}$ & 70 & 30 \\
$\mathrm{D}$ & 60 & 40 \\
\hline
\end{tabular}

Table 2. Hedonic scale evaluation of bhoi cake (Soekarto 1990)

\begin{tabular}{lc}
\hline Test acceptance & Scoring \\
\hline Really like & 5 \\
Like it & 4 \\
Neutral (Ordinary) & 3 \\
Do not like & 2 \\
Very dislike & 1 \\
\hline
\end{tabular}

\section{Proximate analysis of bhoi cake}

The proximate analysis of bhoi cake included: carbohydrate, protein, fat, water, and ash content. Carbohydrate content was carried out according to Luft Schoorl method, protein content using the Kjeldahl method, while fat content using the Soxhletation method. Water content and ash content using the gravimetric method.

\section{Organoleptic test for sensory evaluation}

The test of consumer acceptability was carried by an organoleptic test by 20 fairly trained panelists, who were students of the Faculty of Teacher Training and Education, Syiah Kuala University.

The most preferred product was determined by summing the score values given by the panelists and taking its average. Product with the highest score was the best acceptance product (Adiari et al. 2017).

\section{Statistical analysis}

Statistical analysis was done at a significance level of $\alpha=0.05$. The scores from the consumer acceptance were subjected to analysis of variance (ANOVA). When significant differences in ANOVA were detected, the mean values were compared using the Duncan test.

\section{RESULTS AND DISCUSSION}

\section{The nutritional value of bhoi cake}

The nutritional value of bhoi cake with various content of yellow pumpkin flour was presented in Table 3. The proximate analysis of bhoi cake with the addition of pumpkin flour on various formulas showed that the proximate level was the same as the $9 \%$ fat content, $37 \%$ carbohydrate, $8 \%$ protein, $12 \%$ moisture content and $0.6 \%$ ash content. Additions of $10 \%, 20 \%$, and $30 \%$ pumpkin flour to bhoi cakes did not affect $(p>0.05)$ the proximate level. 
Table 3. The nutritional content of bhoi cake with different substitution levels of wheat flour by yellow pumpkin flour

\begin{tabular}{llllll}
\hline $\begin{array}{l}\text { Treat- } \\
\text { meant }\end{array}$ & $\begin{array}{l}\text { Fat } \\
(\boldsymbol{\%})\end{array}$ & $\begin{array}{l}\text { Carbo- } \\
\text { hydrates } \\
(\boldsymbol{\%})\end{array}$ & $\begin{array}{l}\text { Protein } \\
(\boldsymbol{\%})\end{array}$ & $\begin{array}{l}\text { Water } \\
\text { content } \\
(\boldsymbol{\%})\end{array}$ & $\begin{array}{l}\text { Ash } \\
\text { content } \\
(\boldsymbol{\%})\end{array}$ \\
\hline $\mathrm{A}$ & 9.46 & 37.49 & 8.99 & 12.29 & 0.59 \\
$\mathrm{~B}$ & 9.45 & 37.01 & 8.98 & 12.28 & 0.59 \\
$\mathrm{C}$ & 9.67 & 37.07 & 9.01 & 12.30 & 0.67 \\
$\mathrm{D}$ & 9.60 & 37.05 & 8.99 & 12.27 & 0.60 \\
\hline
\end{tabular}

Note: Formula A (0\% of pumpkin flour), Formula B (20\% of pumpkin flour), Formula C (30\% of pumpkin flour), Formula D (40\% of pumpkin flour)

Table 4. Sensory evaluation of bhoi cake with different levels of pumpkin flour

\begin{tabular}{lllll}
\hline $\begin{array}{l}\text { Treat- } \\
\text { ment }\end{array}$ & Color & Aroma & Taste & Texture \\
\hline A & $4.0 \pm 1.55 \mathrm{~d}$ & $4.4 \pm 0.59 \mathrm{c}$ & $4.0 \pm 0.61 \mathrm{~d}$ & $3.85 \pm 0.67 \mathrm{c}$ \\
B & $4.3 \pm 0.57 \mathrm{c}$ & $4.45 \pm 0.51 \mathrm{~b}$ & $4.15 \pm 0.67 \mathrm{~b}$ & $3.75 \pm 0.71 \mathrm{~d}$ \\
C & $4.5 \pm 0.51 \mathrm{a}$ & $4.55 \pm 0.51 \mathrm{a}$ & $4.55 \pm 0.51 \mathrm{a}$ & $4.05 \pm 0.68 \mathrm{a}$ \\
D & $4.25 \pm 0.71 \mathrm{~b}$ & $4.2 \pm 0.69 \mathrm{~d}$ & $4.1 \pm 0.71 \mathrm{c}$ & $3.9 \pm 0.64 \mathrm{~b}$ \\
\hline
\end{tabular}

Note: 5 = very like, $4=$ like, $3=$ neutral, $2=$ dislike, $1=$ very dislike. Data are presented as mean \pm SD. $(n=20)$. Different notations on the same column are significantly different $(p>0.05)$

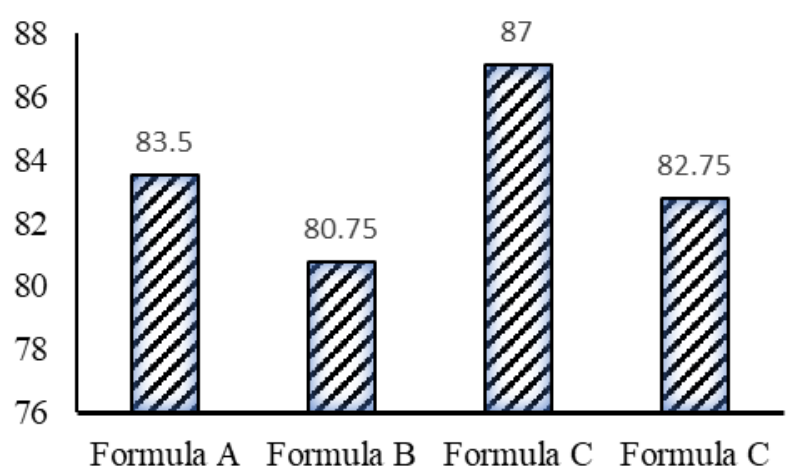

Figure 1. Percentage hedonic quality test of the most liked product (Average Product Value)

\section{Evaluation of sensory characteristics of bhoi cake}

The result of the organoleptic test of bhoi cake with different levels of wheat flour substitution was presented in Table 4. It showed that the substitution of pumpkin flour has an average score of 3.75-4.55 (likes). The most preferred product is formula $\mathrm{C}$ (Figure 1)

Table 4 showed that the color of bhoi cake from formula $\mathrm{C}$ with $30 \%$ substitution of pumpkin flour has the highest score $(4.5 \pm 0.51)$ and significantly different from other formulas $(\mathrm{P}<0.05)$. The lowest score (less acceptable) was obtained in the formula A (control), without substitution of pumpkin flour, which resulted in light yellow bhoi cake color. It can be concluded that the addition of pumpkin flour affects the color of bhoi cake from light yellow to golden yellow. Substitution of $20 \%$ pumpkin flour had a positive effect on bhoi cake acceptability. Caramelization is a non-enzymatic browning process caused by heating sugar, which exceeds its melting point at $170{ }^{\circ} \mathrm{C}-200{ }^{\circ} \mathrm{C}$ to produce brown sugar (Eksin et al. 1971).

Sensory evaluation on the aroma of bhoi cake with pumpkin flour substitution showed that formula $\mathrm{C}$ had the best acceptance indicated by the highest score (4.55), while the lowest score was obtained in formula D with $40 \%$ pumpkin flour substitution. It can be concluded that increasing pumpkin flour may affect the aroma of bhoi cake and resulted in decreasing acceptance of the cake. According to Hendrasty (2004), pumpkin has specific properties with a distinctive aroma. The substitution of pumpkin flour up to $30 \%$ result in more acceptable.

Sensory evaluation on the flavor of bhoi cake with pumpkin flour substitution has the average score from 4 to 4.55 (likes) (Table 4). The highest score (4.55) was bhoi cake with formula $\mathrm{C}$ with $30 \%$ pumpkin flour substitution, while the lowest score was obtained from bhoi cake with formula A (control), without substitution of pumpkin flour. It can be concluded that the addition of pumpkin flour to the taste of bhoi cake is favored by consumers. Taste is a sensation that is received by taste buds in the oral cavity caused by water-soluble compounds that act in the tongue (Roper and Claudhari 2017).

The organoleptic test or sensory evaluation on the texture of bhoi cake results in the average score from 3.75 to 4.05 (like) with the highest score was formula $\mathrm{C}$ and the lowest score was formula B with $20 \%$ of pumpkin flour substitution. Substitution of $20 \%$ pumpkin flour results in more acceptable texture. The texture and consistency of the material will affect the flavor. A study by Różyło et al. (2014) showed that $10 \%$ pumpkin flour substitution result in satisfactory results on the texture of bhoi cake. The overall result of sensory evaluation or organoleptic test of bhoi cake with the pumpkin substitution showed that bhoi cake with formula C (30\% substitution of pumpkin flour) was the most preferred by the panelist.

\section{ACKNOWLEDGEMENTS}

Thank you to the Head and Staff of the Family Welfare Vocational Education Laboratory, Faculty of Teacher Training and Education Universitas Syiah Kuala, Banda Aceh, Indonesia.

\section{REFERENCES}

Adiari NWL, Yogeswara IBA, Putra IMWA. 2017. Development of functional food based on okara flour and black rice flour (Oryza sativa L.) as a snack for obese adolescents. Indonesian J Nutrition, 6 (1): 23-31.

Balkis CP. 2015. Standardization of the Bhoi Cake Recipe by Mixing Yellow Pumpkin Flour, (Cucurbita moschata). [Script] Syiah Kuala University Banda Aceh.

Chigwe CB, Saka VW. 1994. Collection and Characterization of Malawi Pumpkin Germplasm. Zim J Agric Res 32(2):139-149.

Directorate of Nutrition, Ministry of Health RI. 1996. List of food ingredients. Jakarta. 
Eksin NAM, Henderson HM, Townsend RJ. 1971. Biochemistry of foods. Academic Press, New York, San Franscisco, London.

Hendrasty, Henny K. 2003. Pumpkin flour makes and uses it. Yogyakarta. Kanisius.

Joshi VK, Panesar PS. 2017. Specific features of table wine production technology. Sci Tech Fruit Wine Prod, 295-461

Kusińska E. 2007. Effect of sugar addition on textural properties of the half-short cake. J Food Nutr Sci 57(2): 107-110

Nakhon PPS, Jangchud K, Jangchud A, Prinyawiwatkul W. 2017. Comparisons of physicochemical properties and antioxidant activities among pumpkin (Cucurbita moschata L.) flour and isolated starches from fresh pumpkin or flour. Int J Food Sci Tech.52: 2436-2444

Roper SD, Claudhari N. 2017. Taste buds: cells, signals and synapses. Nat Rev Neurosci 18(8): 485-497.
Różyło R, Gawlik-Dziki U, Dziki D, Jakubczyk A, Karaś M, Różyło K. 2014. Wheat bread with pumpkin (Cucurbita maxima L.) pulp as a functional food product. Food Tech Biotechnol. 52(4):430-438

Shahidan N, Irwandi J, Othman R, Zuhanis Y, Hashim HY. 2014. Carotenoid content in different locality of pumpkin (Cucurbita moschata) in Malaysia. Int J Pharm Pharm Sci. 6 (3):29-32

Sinaga S. 2011. The Effect of Flour Substitution and the Type of Stabilizer in Making Pumpkin Cookies. [Thesis] Faculty of agriculture, University of Sumetera Utara Medan.

Soekarto. 1990. Organoleptic assessment for the food and agricultural products industry. Jakarta: Bhatara Aksara.

Zdunić GM, Menković NR, Jadranin MB, Novaković MM, Šavikin KP, Živković JC. 2015. Phenolic compounds and carotenoids in pumpkin fruit and related traditional products. Hem Ind 70 (4) 429-433. 